\title{
Ventilatory inefficiency: a key physiopathological mechanism increasing dyspnea and reducing exercise capacity in chronic obstructive pulmonary disease
}

\author{
Iván Caviedes ${ }^{1,2}$ \\ ${ }^{1}$ Servicio de Enfermedades Respiratorias, Clínica Alemana de Santiago, Chile; ${ }^{2}$ Facultad de Medicina, Clínica Alemana - Universidad del Desarrollo, \\ Santiago, Chile \\ Correspondence to: Iván Caviedes. Facultad de Medicina, Clínica Alemana - Universidad del Desarrollo, Avenida Vitacura 5951, Santiago 5690000, \\ Chile. Email: icaviedes@alemana.cl.
}

Submitted May 15, 2021. Accepted for publication Jun 14, 2021.

doi: $10.21037 /$ jtd-21-834

View this article at: http://dx.doi.org/10.21037/jtd-21-834

Lin et al. (1), remembers an essential principle of physiology, which states that one objective of alveolar ventilation is to clear $\mathrm{CO}_{2}$ production $\left(\mathrm{VCO}_{2}\right)$, maintain an adequate arterial $\mathrm{CO}_{2}$ pressure $\left(\mathrm{PaCO}_{2}\right)$, and control acid-base balance. The central $\mathrm{PCO}_{2}$ set point regulated by the respiratory centers, govern the ventilatory response to depurate $\mathrm{CO}_{2}$. In absence of fixed acids, the disproportionate increment in minute ventilation $(\mathrm{VE})$ for $\mathrm{VCO}_{2}$, indicates inefficiency of ventilation (VI). This mechanism exists particularly in chronic obstructive pulmonary disease (COPD) (1-5), where VI raise subrogated to physiological dead space (VDphys/VT), due to waisted ventilation and the need to control the $\mathrm{PaCO}_{2}$. In consequence, the $\mathrm{VE} / \mathrm{VCO}_{2}$ ratio also increase. As example, a normal individual in moderate exercise requires 20-25 L of ventilation to clear $1 \mathrm{~L}$ of $\mathrm{CO}_{2}$, and patient with COPD frequently overpass $35 \mathrm{~L}$.

This unbalanced ventilation (6-8) diminish exercise capacity (EC), and is closely related to the magnitude of dyspnea $(1-3,9,10)$. With the magnified demand of VE imposed by VI, associated with more expiratory resistance, and less time available for deflation, the pulmonary hyperinflation is potentiated. In their investigation, and performing different measurements of the $\mathrm{VE} / \mathrm{VCO}_{2}$ ratio, in the slope, nadir and intercept, authors describe adequately the correlation between VI and hyperinflation. It is the rule, that COPD patients with greater bronchial obstruction, hyperinflation, mechanical restrictions, and less physical conditioning, present greater functional limitation and major dyspnea. However, from the point of view of gas exchange, VI is also a key physiological alteration, enhancing dyspnea and limiting EC $(3,4,11,12)$.

The mechanical restriction imposed by dynamic hyperinflation is a disadvantageous situation, since the loss of the area of apposition and the flattening of the diaphragm, induce less efficiency in their length/tension relationship. In this way, the pressure/volume relationship is unfavorable, and the work of breathing augment $(1,2,6,7,9)$. During exercise, VI means more ventilatory demand and boost dynamic hyperinflation. As this mechanism progresses, the high central neuronal impulse is dissociated with the depressed response of the respiratory musculature, or neuromechanical uncoupling, bringing the patient closer to ventilatory fatigue $(2,6,7,9)$. In association with dynamic hyperinflation, it also reduces venous return, and the capacity of the right ventricle for pulmonary perfusion, enhancing VD/V'Tphys and VI $(3,4,6,7,9)$.

During an exercise test, the behavior of the VE/ $\mathrm{VCO}_{2}$ slope (Figure 1) shows that its lowest level (nadir) corresponds to the optimization of the ventilation/perfusion (V/Q) ratio by alveolar recruitment. After this stage, more $\mathrm{VE}$ is required to compensate the increased $\mathrm{VCO}_{2}$, due to the buffer effect of $\mathrm{H}_{2} \mathrm{CO}_{3}$ over the rise in lactate. Particularly in COPD, the $\mathrm{VE} / \mathrm{VCO}_{2}$ value at nadir exceeds that of a normal individual, and supposedly it would be magnified in relation to severity, however, this behavior is not directly related $(4,10)$.

In a patient with severe COPD, during exercise, and when hyperinflation and mechanical restrictions do not allow the ventilatory pump to maintain the high demand for $\mathrm{VE}$, the nadir does not overpass that of less severe patients 
A

VE (L/min)

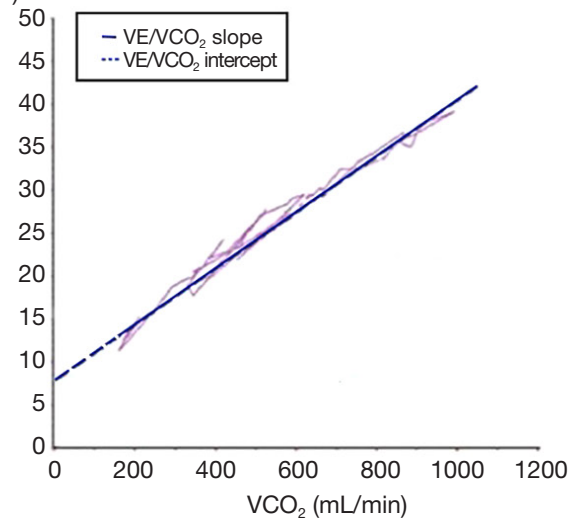

B

$\mathrm{VE} / \mathrm{VCO}_{2}$

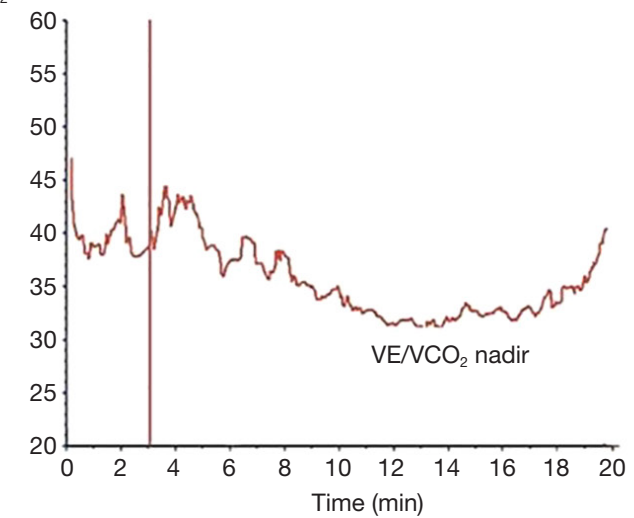

Figure 1 A 55-year-old male with COPD is represented. His FEV1 and DLCO were $47 \%$ and $41 \%$ of their predicted values. At the end of the exercise, he reached a $\mathrm{VO}_{2} \max$ and a $\mathrm{Wmax}$ of $60 \%$ and $65 \%$ of their reference values, his inspiratory capacity decreased by $600 \mathrm{~mL}$, and the $\mathrm{VE} / \mathrm{VCO}_{2}$ measured in the slope was 38. (A) The $\mathrm{VE} / \mathrm{VCO}_{2}$ slope and the $\mathrm{VE} / \mathrm{VCO}_{2}$ intercept are showed. (B) The nadir of the $\mathrm{VE} / \mathrm{VCO}_{2}$ slope is presented. $\mathrm{VO}_{2} \mathrm{max}$, maximal oxygen consumption; $\mathrm{Wmax}$, maximal power; $\mathrm{VE}$, minute volume; $\mathrm{VCO}_{2}, \mathrm{CO}_{2}$ production; FEV1, forced expiratory volume in 1 second; DLCO, carbon monoxide diffusion capacity.

$(1,3,4)$. Furthermore, it is likely that the $\mathrm{PCO}_{2}$ set point will also be altered, and the tight control of $\mathrm{PaCO}_{2}$ will be lost. The study of Lin et al. (1) provides more information to these concepts, showing that the intercept of the VE/ $\mathrm{VCO}_{2}$ slope (prolongating its linear part to the $\mathrm{y}$-axis) (Figure 1), is significantly correlated with static and dynamic hyperinflation. In this context, $\mathrm{VE} / \mathrm{VCO}_{2}$ determinations at the intercept seems to better interpret VI and COPD severity $(1,3,4)$.

The elimination of $\mathrm{CO}_{2}$, and the efficiency of ventilation, intertwine respiratory and cardiac function. In heart failure, when pulmonary perfusion decline, VD/VTphys, VE/ $\mathrm{VCO}_{2}$ ratio and dyspnea increases, and $\mathrm{EC}$ diminish. In some studies, the prognostic value of $\mathrm{VO}_{2}$ max, or the $\mathrm{VE} /$ $\mathrm{VCO}_{2}$ slope adds valuable information to the left ventricular ejection fraction to discriminate the risk of mortality, left ventricular support, and heart transplantation (13-15). In fact, the American Heart Association and their European counterpart describes 4 levels of severity, according to the grade of VI (16).

The effect of COPD treatments on VI are encouraging and under investigation. As an example, lung volume reduction surgery (LVRS) improves mechanical restrictions and ventilatory efficiency. Armstrong et al. compared 55 patients undergoing LVRS with 25 controls from the National Emphysema Treatment Trial, comparing EC at baseline and at 6 months after surgery. They revealed that patients undergoing LVRS improved maximal Oxygen consumption $\left(\mathrm{VO}_{2} \mathrm{max}\right)$, maximal power, and tidal volume, concomitantly with a decline in the $\mathrm{VE} / \mathrm{VCO}_{2}$ ratio (17). Consequently, studies in lung volume reduction with endobronchial valves are expected. Additionally, by their action in hyperinflation, long acting bronchodilators can attenuate VDphys/VT alterations, and it is assumed that by ameliorating the mechanics of the ventilatory pump, diminish the demand for VE and VI, and delay the pattern of ventilatory fatigue $(3,4)$. It is well known, that the administration of oxygen during exercise, lowers the sympathetic impulse of the respiratory centers, and reduce $\mathrm{VE}$ and dyspnea, also suggesting an VI improvement $(3,4)$.

As the authors describe, prognostic studies have been performed with the $\mathrm{VE} / \mathrm{VCO}_{2}$ index as an independent parameter. In a 4-year follow-up of 288 COPD patients, it was demonstrated that the enhanced $\mathrm{VE} / \mathrm{VCO}_{2}$ ratio at nadir, was the only variable related to respiratory and all-cause mortality. When was associated with the inspiratory fraction, its performance as a predictor of mortality grew $(4,12)$. In lung cancer surgery in COPD patients, the increased VE/ $\mathrm{VCO}_{2}$ ratio has exceeded $\mathrm{VO}_{2} \mathrm{max}$, as a predictor of mortality. Shafiek et al., in a 1-year prospective study in 83 patients, showed that the raise in the $\mathrm{VE} / \mathrm{VCO}_{2}$ ratio was associated with $41 \%$ of complications and $4 \%$ of deaths, overpassing $\mathrm{VO}_{2} \max$ as a predictor (18). Torchio et al., in a retrospective study of 145 patients, the 30-day mortality was studied, and 
revealed that the elevated $\mathrm{VE} / \mathrm{VCO}_{2}$ slope prior to surgery, was an independent predictor of mortality, even with an acceptable $\mathrm{VO}_{2} \max$ for surgery (19).

The conclusions of Lin et al. (1) reinforce these concepts, remarking the relevance of the $\mathrm{VE} / \mathrm{VCO}_{2}$ ratio at the intercept. Even more, the importance of the VE/ $\mathrm{VCO}_{2}$ ratio at rest has been described. In a retrospective study of 284 COPD patients, Neder et al., demonstrated that an enhanced $\mathrm{VE} / \mathrm{VCO}_{2}$ ratio at rest, is associated independently, or with hyperinflation, with the magnitude of dyspnea during exercise (20). Considering that many patients with severe COPD are not in a position to carry out a walking test, new studies analyzing determinations of the $\mathrm{VE} / \mathrm{VCO}_{2}$ ratio at lower exercise intensity, or in the intercept, or at rest, are needed to include these parameters, in the evaluation of lung function $(1,20,21)$.

\section{Acknowledgments}

Funding: None.

\section{Footnote}

Provenance and Peer Review: This article was commissioned by the editorial office, Fournal of Thoracic Disease. The article did not undergo external peer review.

Conflicts of Interest: The author has completed the ICMJE uniform disclosure form (available at http://dx.doi. org/10.21037/jtd-21-834). The author has no conflicts of interest to declare.

Ethical Statement: The author is accountable for all aspects of the work in ensuring that questions related to the accuracy or integrity of any part of the work are appropriately investigated and resolved.

Open Access Statement: This is an Open Access article distributed in accordance with the Creative Commons Attribution-NonCommercial-NoDerivs 4.0 International License (CC BY-NC-ND 4.0), which permits the noncommercial replication and distribution of the article with the strict proviso that no changes or edits are made and the original work is properly cited (including links to both the formal publication through the relevant DOI and the license). See: https://creativecommons.org/licenses/by-ncnd $/ 4.0 \%$.

\section{References}

1. Lin F, Nie S, Zhao R, et al. Intercept of minute ventilation versus carbon dioxide output relationship as an index of ventilatory inefficiency in chronic obstructive pulmonary disease. J Thorac Dis 2021;13:1553-63.

2. O'Donnell DE, Revill SM, Webb KA. Dynamic hyperinflation and exercise intolerance in chronic obstructive pulmonary disease. Am J Respir Crit Care Med 2001;164:770-7.

3. O'Donnell DE, Elbehairy AF, Faisal A, et al. Exertional dyspnoea in COPD: the clinical utility of cardiopulmonary exercise testing. Eur Respir Rev 2016;25:333-47.

4. Neder JA, Berton DC, Arbex FF, et al. Physiological and clinical relevance of exercise ventilatory efficiency in COPD. Eur Respir J 2017;49:1602036.

5. Dempsey JA, Smith CA. Pathophysiology of human ventilatory control. Eur Respir J 2014;44:495-512.

6. O'Donnell DE, Laveneziana P, Webb K, et al. Chronic obstructive pulmonary disease: clinical integrative physiology. Clin Chest Med 2014;35:51-69.

7. O'Donnell DE, Elbehairy AF, Berton DC, et al. Advances in the Evaluation of Respiratory Pathophysiology during Exercise in Chronic Lung Diseases. Front Physiol 2017;8:82.

8. Mahler DA, O'Donnell DE. Recent advances in dyspnea. Chest 2015;147:232-41.

9. O'Donnell DE, Elbehairy AF, Webb KA, et al. The Link between Reduced Inspiratory Capacity and Exercise Intolerance in Chronic Obstructive Pulmonary Disease. Ann Am Thorac Soc 2017;14:S30-9.

10. Weatherald J, Sattler C, Garcia G, et al. Ventilatory response to exercise in cardiopulmonary disease: the role of chemosensitivity and dead space. Eur Respir J 2018;51:1700860.

11. Caviedes IR, Delgado I, Soto R. Ventilatory inefficiency as a limiting factor for exercise in patients with COPD. Respir Care 2012;57:583-9.

12. Neder JA, Alharbi A, Berton DC, et al. Exercise Ventilatory Inefficiency Adds to Lung Function in Predicting Mortality in COPD. COPD 2016;13:416-24.

13. Tumminello G, Guazzi M, Lancellotti P, et al. Exercise ventilation inefficiency in heart failure: pathophysiological and clinical significance. Eur Heart J 2007;28:673-8.

14. Ponikowski P, Francis DP, Piepoli MF, et al. Enhanced ventilatory response to exercise in patients with chronic heart failure and preserved exercise tolerance: marker of 
abnormal cardiorespiratory reflex control and predictor of poor prognosis. Circulation 2001;103:967-72.

15. Nadruz W Jr, West E, Sengeløv M, et al. Prognostic Value of Cardiopulmonary Exercise Testing in Heart Failure With Reduced, Midrange, and Preserved Ejection Fraction. J Am Heart Assoc 2017;6:e006000.

16. Guazzi M, Adams V, Conraads V, et al. EACPR/AHA Scientific Statement. Clinical recommendations for cardiopulmonary exercise testing data assessment in specific patient populations. Circulation 2012;126:2261-74.

17. Armstrong HF, Dussault NE, Thirapatarapong $W$, et al. Ventilatory efficiency before and after lung volume reduction surgery. Respir Care 2015;60:63-71.

18. Shafiek H, Valera JL, Togores B, et al. Risk of postoperative complications in chronic obstructive lung

Cite this article as: Caviedes I. Ventilatory inefficiency: a key physiopathological mechanism increasing dyspnea and reducing exercise capacity in chronic obstructive pulmonary disease. J Thorac Dis 2021;13(7):4614-4617. doi: 10.21037/jtd-21-834 diseases patients considered fit for lung cancer surgery: beyond oxygen consumption. Eur J Cardiothorac Surg 2016;50:772-9.

19. Torchio R, Guglielmo M, Giardino R, et al. Exercise ventilatory inefficiency and mortality in patients with chronic obstructive pulmonary disease undergoing surgery for non-small-cell lung cancer. Eur J Cardiothorac Surg 2010;38:14-9.

20. Neder JA, Berton DC, Marillier M, et al. Resting $\mathrm{VE} / \mathrm{VCO}_{2}$ adds to inspiratory capacity to predict the burden of exertional dyspnoea in COPD. Eur Respir J 2020;56:1902434.

21. Caviedes I, Soto R, Herth F. The determination of ventilatory inefficiency at rest in COPD: the expected parameter. Eur Respir J 2020;56:2002947. 